\title{
SOLUSI NUMERIK PERSAMAAN DIFUSI NEUTRON PADA TERAS REAKTOR NUKLIR DENGAN METODE ITERASI JACOBI PARALEL MENGGUNAKAN OPENMP
}

\author{
Frans Madah Basoaro Wau, Imam Taufiq dan Afdal \\ Program Pascasarjana, Jurusan Fisika FMIPA Universitas Andalas \\ Kampus Unand, Limau Manis, Padang, 25163 \\ email : frans_nise107@yahoo.com
}

\begin{abstract}
ABSTRAK
Perhitungan Persamaan difusi neutron 2-dimensi telah berhasil diselesaikan secara paralel dengan menggunakan metoda Jacobi. Program ditulis dalam bahasa $\mathrm{C}++$ menggunakan OpenMP. Dari proses benchmarking nilai fluks neutron dengan program FI-ITBCHI diperoleh bahwa kode program yang dibuat valid dengan akurasi hingga 6 angka penting. Hasil running program menunjukkan bahwa program yang dibuat bersifat scalable, baik pada prosesor single-core maupun multi-core. Nilai speedup tertinggi dicapai dengan menggunakan jumlah thread sama dengan jumlah core prosesor. Untuk prosesor dengan jumlah core 2 dicapai nilai speedup 1,28 sedangkan untuk core 4 nilai speedup-nya adalah 1,53.
\end{abstract}

Kata Kunci : Persamaan difusi, metoda Jacobi, komputasi paralel, OpenMP, speedup

\begin{abstract}
The calculation of 2-dimensional neutron diffusion equation has been succesfully done parallely using Jacobi method. The program is written in C++ using OpenMP. As a result of benchmarking process of neutron flux values by FI-ITBCHI, the written program is valid within 6 significant figures. The result of the running program showed that the written program is scalable, both on single-core processors and multi-core processors. Highest speedup is achieved by setting the number of threads the same as the number of cores. For processor with 2 core, the achieved speedup is 1.28 and for 4 cores the speedup is 1.53 .
\end{abstract}

Key words : diffusion equation, Jacobi method, parallel computation, OpenMP, speedup

\section{PENDAHULUAN}

Seiring dengan kemajuan teknologi dibidang mikroprosesor, komputer-komputer saat ini telah memiliki prosesor yang lebih dari satu atau yang lebih dikenal dengan istilah multicore processor. Komputer dengan multi-core processor ini sangat mendukung kebutuhan sebuah komputasi yang rumit, dengan ketentuan algoritma program atau aplikasi tersebut haruslah berbasis paralel. Gagasan dasar dari pemrograman paralel ini adalah membagi permasalahan sehingga menjadi lebih kecil untuk dikerjakan oleh setiap prosesor yang ada dalam waktu yang bersamaan. Dengan begitu, waktu pengeksekusian akan lebih singkat.

Dalam analisis reaktor, perhitungan persamaan difusi neutron seringkali dilakukan secara berulang-ulang. Karenanya secara keseluruhan waktu perhitungan persamaan difusi neutron menjadi cukup lama. Dengan demikian percepatan perhitungan persamaan difusi ini akan sangat membantu mempercepat analisis reaktor secara keseluruhan. Untuk dapat memperoleh nilai distribusi fluks neutron dari persamaan difusi, maka geometri teras 
reaktor akan dibagi menjadi bagian-bagian (mesh) kecil. Persamaan difusi ini akan diintegrasi dan didiskritisasi sehingga persamaannya akan menjadi bentuk matriks. Matriks inilah yang akan diselesaikan menggunakan iterasi Jacobi, dimana metode Jacobi merupakan metode iterasi yang mudah diparalelisasikan dibandingkan metode iterasi lainnya, dan OpenMP sebagai paralelisasinya.

OpenMP (Open Multi-Processing) adalah program aplikasi antarmuka (application programming interface/API). OpenMP ini hanya sesuai untuk bahasa pemrograman $\mathrm{C}$, $\mathrm{C}++$ dan Fortran. OpenMP mendukung kegiatan yang penggunaan memorinya digunakan dalam waktu yang bersamaan (shared-memory).

Penelitian tentang komputasi parallel khususnya yang berhubungan tentang penelitian ini telah dilakukan antara lain, Su'ud, dkk (2001) yaitu perhitungan konstanta grup nuklir, dijalankan pada cluster multi-PC heterogen (tak-simetris) yang dihubungkan dengan fast ethernet card 100-base dan menggunakan PVM (Parallel Virtual Machine) pada platform Linux. Jenis prosesor yang digunakan adalah AMD K-6 dan Athlon dengan kecepatan clock CPU berkisar dari $300 \mathrm{MHz}$ hingga $500 \mathrm{MHz}$. Penggunaan fast ethernet dengan kecepatan maksimum $100 \mathrm{Mbps}$ masih mampu meningkatkan kinerja paralelisasi mengingat bahwa saat itu yang digunakan adalah prosesor dengan frekuensi clock CPU pada orde ratusan $\mathrm{MHz}$, Taufiq (2010) melakukan paralelisasi perhitungan burnup bahan bakar pada reaktor cepat dengan bahan bakar UN-PuN (Uranium Nitrida dan Plutonium Nitrida) menggunakan pendingin $\mathrm{Pb}-\mathrm{Bi}$, dengan hasil bahwa dengan menggunakan Intel TBB (Threading Building Block) dan $\mathrm{C}++$ telah berhasil dicapai speedup pada PC dengan prosesor quad-core sebesar 3,58 dan skalabilitas program dipenuhi. Sastri (2011) menyusun kode program perhitungan Persamaan difusi neutron 2-dimensi dengan metode Jacobi yang ditulis dalam bahasa $\mathrm{C}++$ dan intel TBB, dengan hasil untuk prosesor intel i5 $23203 \mathrm{GHz}$, didapatkan speedup tertinggi sebesar 3,09, sedangkan untuk intel atom N550 didapatkan speedup tertinggi yaitu 1,51.

Tujuan dilakukannya penelitian ini adalah untuk membuat kode program solusi numerik Persamaan difusi neutron pada teras reaktor nuklir dengan metode iterasi Jacobi paralel menggunakan OpenMP, dan menganalisis tingkat ketelitian program dengan membandingkan hasil keluaran program dengan FI-ITBCHI yang sudah dianggap standar. Dengan dihasilkannya kode program ini, diharapkan dapat membantu mempercepat perhitungan Persamaan difusi neutron yang akhirnya juga dapat membantu perhitungan analisis reaktor nuklir.

\section{METODE}

Pada penelitian ini, perhitungan Persamaan difusi neutron dibatasi pada geometri teras berbentuk silinder dengan distribusi bahan bakar homogen konsentris. Dengan demikian persoalan geometri dapat direduksi menjadi 2-dimensi. Sedangkan tipe reaktor yang digunakan dalam perhitungan ini adalah reaktor cepat dengan bahan bakar UN-PuN. Program dibuat menggunakan bahasa pemrograman C++ pada Microsoft Visual Studio 2010 Ultimate dan OpenMP 2.0 yang telah terintegrasi di dalamnya. Program dijalankan pada komputer 2 core (intel core i3 3120M) dan 4 core (intel core i7 3770). Program di benchmark dengan program FI-ITBCHI. Diagram alir penelitian yang telah dilakukan seperti pada Gambar 1 berikut : 


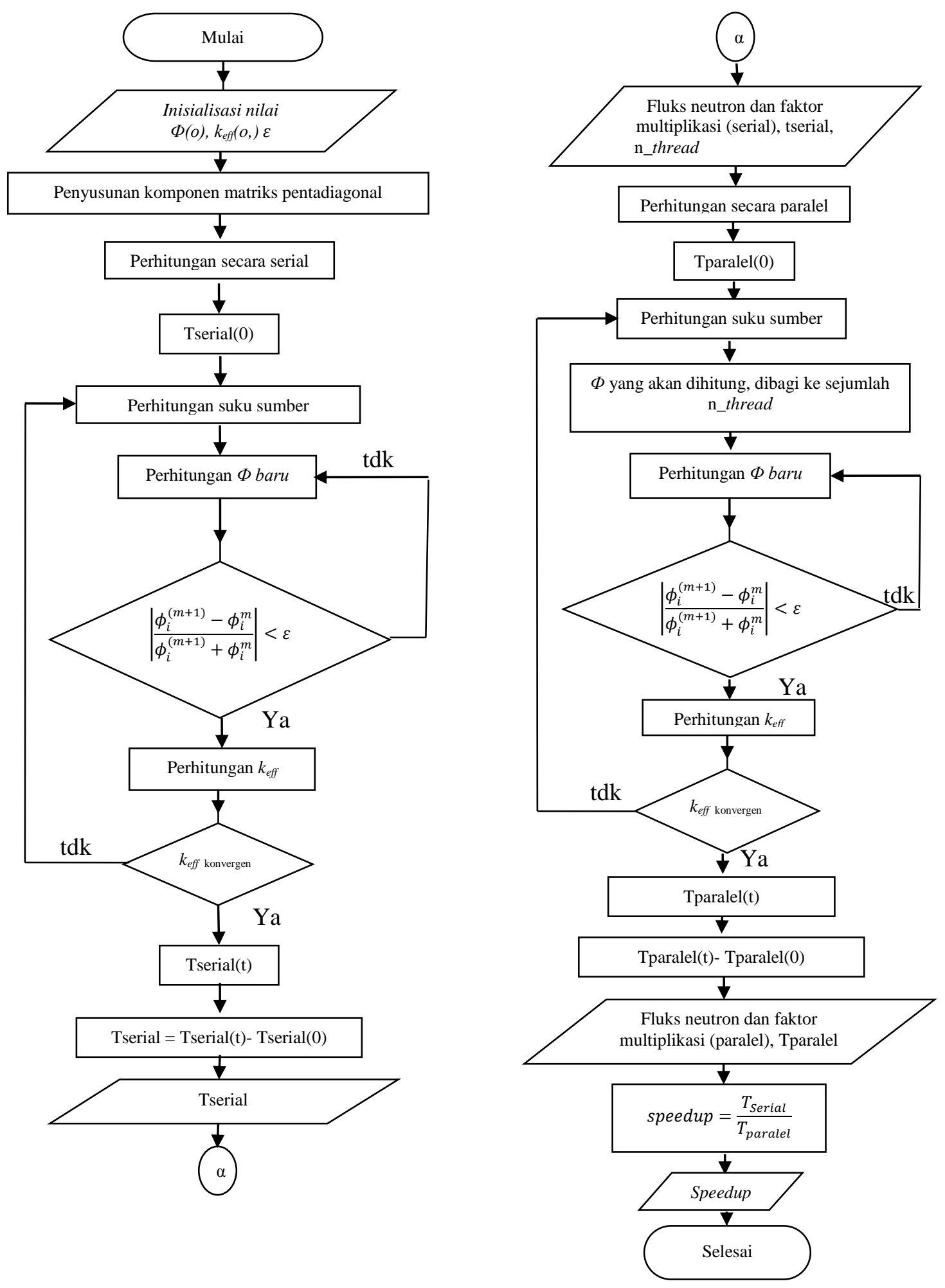

Gambar 1. Diagram alir perhitungan difusi neutron 


\section{Perhitungan Distribusi Fluks Neutron}

Perhitungan distribusi fluks neutron akan dilakukan dengan metode penghampiran pada persamaan difusi. Geometri teras reaktor yang ditinjau berbentuk silinder sebagaimana tampak pada Gambar 2. Persamaan difusi neutron multigrup dapat dituliskan sebagai berikut (Stacey, 2001):

$$
\begin{aligned}
& -\vec{\nabla} \cdot D_{g}(\vec{r}) \vec{\nabla} \phi_{g}(\vec{r})+\Sigma_{r, g}(\vec{r}) \phi_{g}(\vec{r})=\frac{\chi_{g}}{k_{e f f}} \sum_{g^{\prime}=1}^{G} v \Sigma_{f, g^{\prime}}(\vec{r}) \phi_{g^{\prime}}(\vec{r}) \\
& +\sum_{g^{\prime}=1}^{G} \sum_{s, g^{\prime} \rightarrow g}(\vec{r}) \phi_{g^{\prime}}(\vec{r})
\end{aligned}
$$

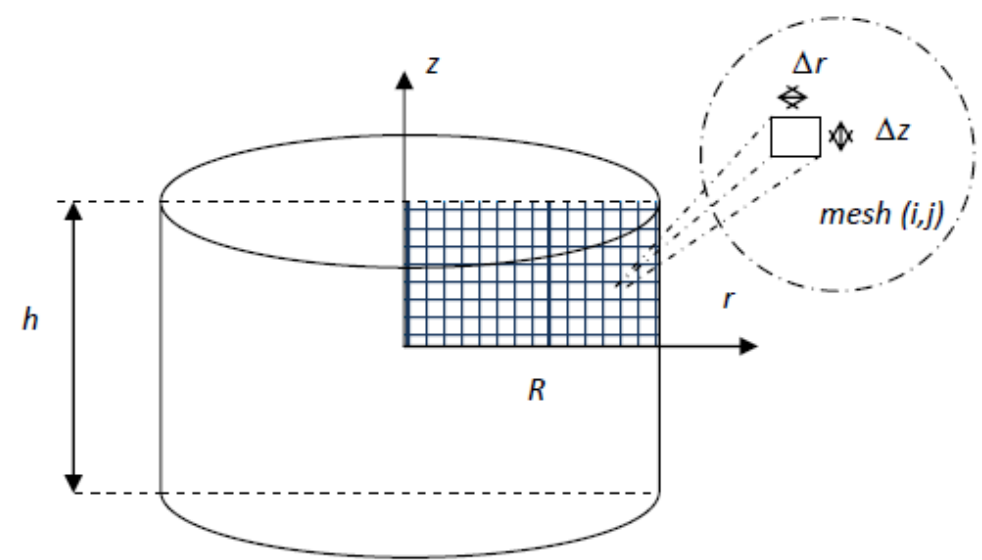

Gambar 2. Geometri teras reaktor berbentuk silinder

dengan indeks bawah $g$ dan $g^{\prime}$ menunjukkan nomor grup neutron, $\chi_{g}$ adalah probabilitas bahwa neutron hasil fisi mempunyai energi dalam daerah grup $g, D$ adalah tetapan difusi, $\phi$ adalah fluks neutron, $\Sigma_{r}$ dan $\Sigma_{f}$ masing-masing adalah tampang lintang removal makroskopik dan tampang lintang fisi makroskopik, $k_{\text {eff }}$ adalah faktor multiplikasi efektif neutron. $\Sigma_{s, g^{\prime} \rightarrow g}$ bermakna probabilitas neutron dari grup $g^{\prime}$ terhambur ke grup $g$ (dikenal dengan nama group-transfer cross section). Pada Gambar 2, jika diasumsikan distribusi bahan bakar bersifat simetris radial, maka perhitungan dapat dilakukan dengan menggunakan koordinat silinder 2-dimensi $(r, z)$. Bagian teras reaktor yang ditinjau dibagi menjadi bagian-bagian kecil yang disebut mesh spasial yang posisinya ditandai dengan indeks $(i, j)$. Dengan nilai $i=1,2, \ldots, i-1, i$ dan $j=1,2, \ldots, j-1, j$. Persamaan (1) diintegrasikan terhadap ruang dan waktu menghasilkan Persamaan (2), (3), (4) dan (5).

$$
\begin{aligned}
& -\gamma_{i, j} \phi_{g_{i, j-1}}+\left(\beta_{i, j}-\alpha_{1, j}\right) \phi_{g_{1, j}}-\alpha_{2, j} \phi_{g_{, 2, j}}-\gamma_{1, j+1} \phi_{g_{, 1, j+1}}=S_{g, 1, j} \\
& -\gamma_{I, j} \phi_{g_{I, j-1}}-\alpha_{I, j} \phi_{g_{I-1, j}}+\beta_{I, j} \phi_{g_{I, j}}-\gamma_{I, j+1} \phi_{g_{I I, j+1}}=S_{g, I, j} \\
& -\alpha_{i, 1} \phi_{g_{, i-1,1}}+\beta_{i, 1} \phi_{g_{, i, 1}}-\alpha_{i+1,1} \phi_{g_{, i+1,1}}-\gamma_{i, 2} \phi_{g_{i, 2}}=S_{g, i, 2} \\
& -\gamma_{i, J} \phi_{g_{, i, J-1}}-\alpha_{i, J} \phi_{g_{, i-1, J}}+\beta_{i, J} \phi_{g_{, i, J}}-\alpha_{i+1, J} \phi_{g_{, i+1, J}}-\gamma_{i, J+1} \phi_{g_{i, J+1}}=S_{g, i, J}
\end{aligned}
$$


Kemudian Persamaan (2), (3), dan (4) dapat disusun ke dalam sebuah matriks sparse pentadiagonal $\mathbf{A}$ yang mengandung variabel $(\alpha, \beta, \gamma)$ yang berisi nilai fluks dan matriks $\mathbf{S}$ yang berisi suku sumber neutron, sehingga Persamaan difusi neutron dapat dituliskan sebagai Persamaan, yaitu:

$\mathrm{A} \Phi=\mathrm{S}$

Jika matriks A merupakan matriks non-singular maka penyelesaian Persamaan (6) adalah (Varga, 2009) :

$\Phi=\mathrm{A}^{-1} \mathrm{~S}$

dengan $\mathrm{A}^{-1}$ adalah invers dari matriks $\mathrm{A}$. Sedangkan matriks $\mathrm{A}$ dapat diurai (dekomposisi) menjadi penjumlahan dari matriks diagonal $\mathrm{D}$, matriks segitiga-atas (upper-triangular) $\mathrm{U}$, dan matriks segitiga-bawah (lower-triangular) L, seperti dituliskan di bawah ini.

$\mathrm{A}=\mathrm{D}+\mathrm{U}+\mathrm{L}$

Dengan demikian Persamaan (8) dapat dituliskan sebagai

$\phi=-D^{-1}(U+L) \phi+-D^{-1} S$

Persamaan iteratif dari Persamaan (9) dapat ditulis

$a_{i, i} \phi_{i}^{m+1}=-\Sigma_{\mathrm{j}=1}^{\mathrm{n}} a_{i, j} \phi_{j}^{m}+S_{i}, 1 \leq i \leq n, m \geq 0$

dengan $\phi_{i}^{0}$ adalah nilai tebakan awal. Kemudian Persamaan (10) dapat ditulis ke dalam bentuk

$\phi_{i}^{m+1}=-\Sigma_{\mathrm{j}=1}^{\mathrm{n}} \frac{a_{i, j}}{a_{i, i}} \phi_{j}^{m}+\frac{s_{i}}{a_{i, i}}, 1 \leq i \leq n, m \geq 0$

Perhitungan iteratif seperti Persamaan (11) disebut sebagai metode Jacobi, atau dikenal dengan total-step iterative method (Varga, 2009). Persamaan in yang akan diparalelkan, dan dipakai untuk menyelesaikan persamaan difusi yang telah diubah dalam bentuk matriks.

\section{Hukum Amdahl}

Menurut Amdahl ada bagian kecil dari sebuah program yang tidak dapat lagi diparalelkan, akan membatasi peningkatan kecepatan yang dapat dicapai dari paralelisasi secara keseluruhan. Semua masalah mengandung bagian yang dapat diparalelkan dan bagian yang tidak dapat diparalelkan juga. Persamaan untuk mengetahui speedup yang didapatkan adalah :

SpeedUp $=\frac{T_{\text {serial }}}{T_{\text {paralel }}}$

dengan $T_{\text {serial }}$ adalah waktu eksekusi program versi serial dan $T_{\text {paralel }}$ adalah waktu eksekusi program versi parallel. 


\section{Komputasi Paralel}

Komputasi paralel adalah proses atau pekerjaan komputasi di komputer dengan memakai suatu bahasa pemrograman yang dijalankan secara paralel pada saat bersamaan. Prinsip dari komputasi paralel adalah melakukan proses komputasi dengan menggunakan 2 atau lebih CPU/Processor dalam suatu komputer yang sama atau komputer yang berbeda (cluster of PCs). Setiap masalah dibagi kedalam beberapa instruksi kemudian dikirim ke prosesor yang tersedia dan eksekusi dilakukan secara serentak. Alasan utama dilakukannya paralelisasi adalah untuk mendapatkan waktu yang lebih singkat dalam menjalankan program. Penggunaan komputasi paralel merupakan pilihan yang cukup handal pada saat ini untuk tugas komputasi yang berat.

\section{HASIL DAN DISKUSI}

\section{Hasil Benchmarking}

Program yang ditulis terdiri atas bagian serial dan paralel. Masing-masing program mempunyai masukan dan keluaran yang sama. Hasil running program berupa distribusi fluks yang kemudian dinormalisasi, didapatkan grafik nya seperti pada Gambar 3.

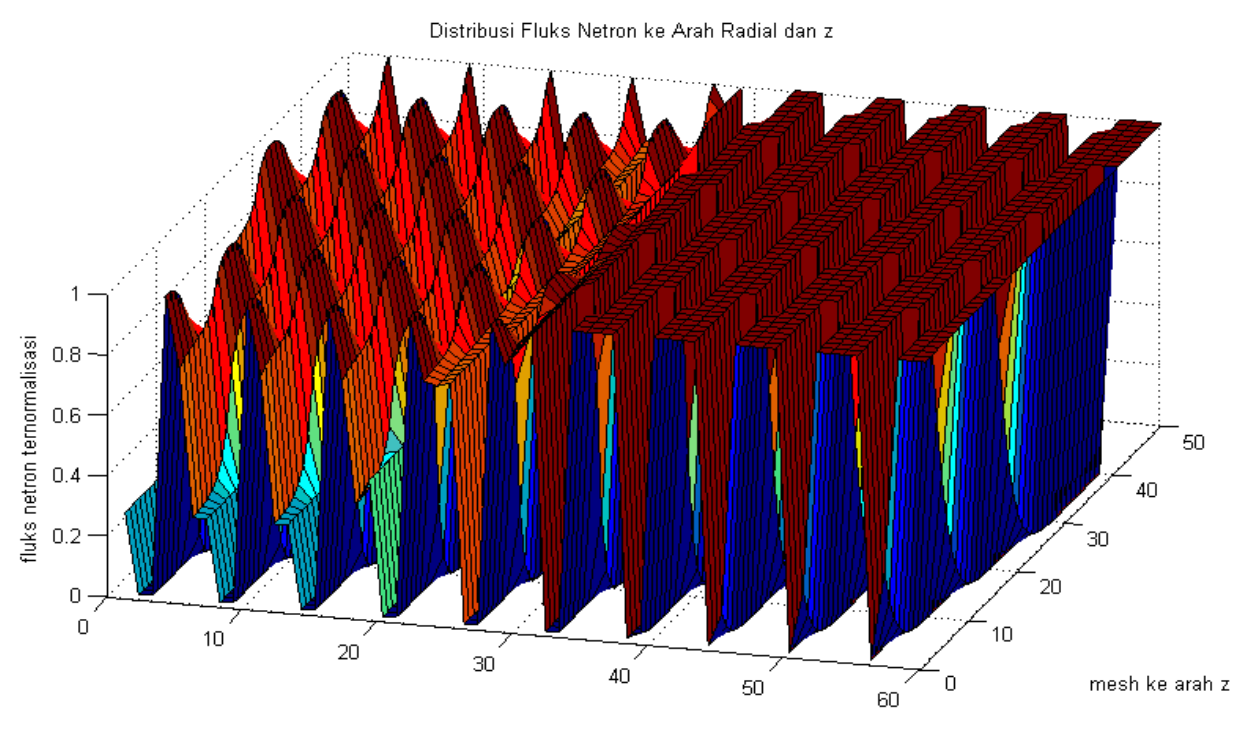

mesh ke arah radial

Gambar 3. Distribusi fluks neutron ke arah radial dan z

Hasil validasi program dengan program FI-ITBCHI yang dianggap menjadi standar dengan hasil perhitungan yang sesuai dengan batas konvergensi, dapat dilihat pada Tabel 1 dan Gambar 4.

Hasil keluaran program yang ditulis menggunakan $\mathrm{C}++$ dan OpenMP ternyata memiliki tingkat kesamaan hingga 6 angka dibelakang koma dengan program FI-ITBCHI. Perbedaan yang paling mendasar adalah, untuk program FI-ITBCHI ditulis dengan menggunakan bahasa pemrograman Delphi dan menggunakan SOR sebagai metode iterasi dalam penyelesaian, sedangkan penulis menggunakan bahasa pemprograman $\mathrm{C}++$ dan OpenMP serta menggunakan Jacobi sebagai metode iterasi. 
Tabel 1. Perbandingan nilai fluks untuk grup ke-8 pada arah-z

\begin{tabular}{|c|c|c|c|c|c|}
\hline \multicolumn{6}{|c|}{ Fluks Neutron cepat (grup ke-8) } \\
\hline No. & $\begin{array}{ll}\text { C++ } & \text { dan } \\
\text { OpenMP }\end{array}$ & $\begin{array}{l}\text { FI-ITBCHI dan } \\
\text { Delphi }\end{array}$ & No. & $\mathrm{C}++$ dan OpenMP & $\begin{array}{l}\text { FI-ITBCHI } \\
\text { dan Delphi }\end{array}$ \\
\hline 1 & 0.1131181893 & 0.1131181435 & 26 & 0.3403146061 & 0.3403146714 \\
\hline 2 & 0.1131195982 & 0.1131195768 & 27 & 0.3486065429 & 0.3486065167 \\
\hline 3 & 0.1131228999 & 0.1131228965 & 28 & 0.3653142076 & 0.3653142086 \\
\hline 4 & 0.1131292468 & 0.1131292354 & 29 & 0.398382275 & 0.398382209 \\
\hline 5 & 0.1131409031 & 0.1131409131 & 30 & 0.4131312655 & 0.4131312977 \\
\hline 6 & 0.1131621237 & 0.1131621326 & 31 & 0.4187450118 & 0.4187450215 \\
\hline 7 & 0.1132008272 & 0.1132008675 & 32 & 0.4183964376 & 0.4183964865 \\
\hline 8 & 0.1132717416 & 0.1132717865 & 33 & 0.4120964461 & 0.4120964876 \\
\hline 9 & 0.1134023149 & 0.1134023124 & 34 & 0.3968014015 & 0.3968014243 \\
\hline 10 & 0.1136438312 & 0.1136438653 & 35 & 0.3649431718 & 0.3649431987 \\
\hline 11 & 0.1140923441 & 0.1140923857 & 36 & 0.3006734796 & 0.3006734153 \\
\hline 12 & 0.1149281677 & 0.1149281893 & 37 & 0.1186721414 & 0.1186721657 \\
\hline 13 & 0.11649048 & 0.116490421 & 38 & 0.03980231912 & 0.0398023187 \\
\hline 14 & 0.119418455 & 0.119418497 & 39 & 0.01335426204 & 0.01335426143 \\
\hline 15 & 0.1249185874 & 0.1249185853 & 40 & 0.004482038657 & 0.004482038875 \\
\hline 16 & 0.1352716249 & 0.1352716121 & 41 & 0.001504763802 & 0.001504763176 \\
\hline 17 & 0.1547948876 & 0.1547948164 & 42 & 0.0005053490706 & 0.0005053490153 \\
\hline 18 & 0.191670834 & 0.19167089 & 43 & 0.0001697613581 & 0.0001697613985 \\
\hline 19 & 0.2652663843 & 0.2652663865 & 44 & 0.00005704330857 & 0.0000570433678 \\
\hline 20 & 0.3013861269 & 0.3013861153 & 45 & 0.0000191727196 & 0.0000191727053 \\
\hline 21 & 0.3183256454 & 0.3183256545 & 46 & 0.000006445711853 & 0.000006445711856 \\
\hline 22 & 0.326415672 & 0.326415665 & 47 & 0.000002167512122 & 0.000002167512942 \\
\hline 23 & 0.3305578411 & 0.3305578673 & 48 & 0.0000007290398868 & 0.0000007290398841 \\
\hline 24 & 0.3332280241 & 0.3332280013 & 49 & 0.0000002452652658 & 0.0000002452652854 \\
\hline 25 & 0.3359726427 & 0.3359726415 & 50 & 0.00000008253002119 & 0.0000000825300534 \\
\hline
\end{tabular}




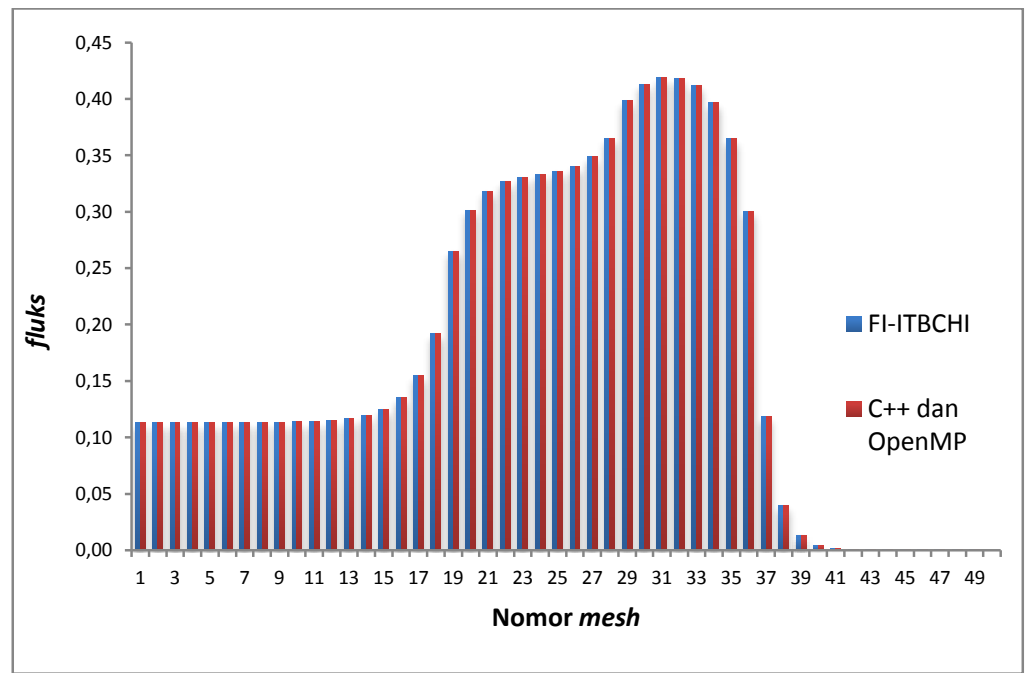

Gambar 4. Perbandingan distribusi Fluks neutron pada C++ dan OpenMP dengan FIITBCHI

Persamaan difusi diselesaikan dengan menggunakan iterasi Jacobi dimana proses iterasi akan berhenti jika sampai pada batas konvergensi yaitu $10^{-6}$. Ke konvergenan didapatkan setelah mencapai iterasi ke-114.

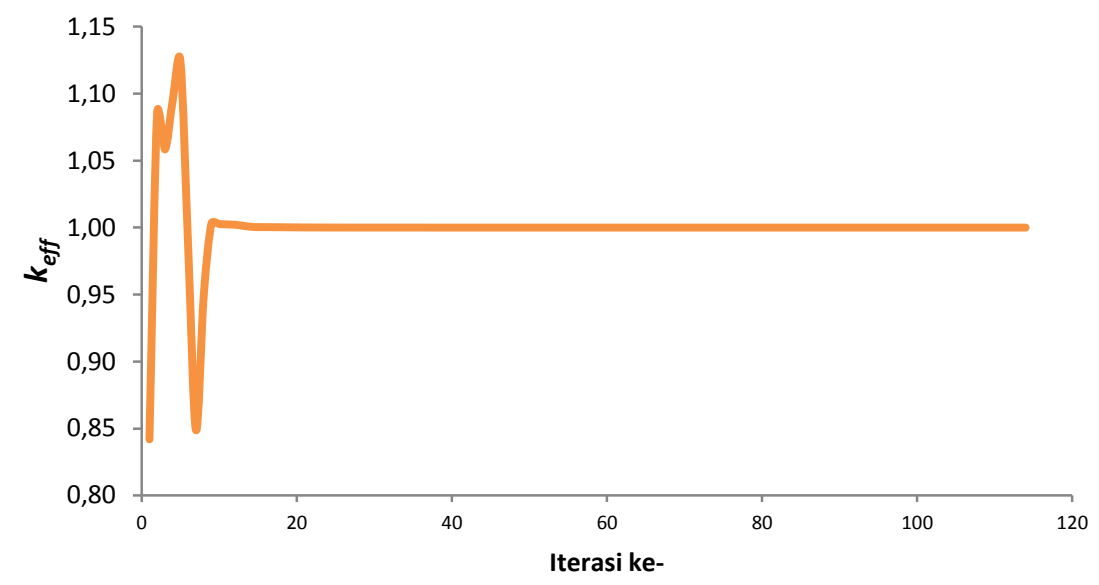

Gambar 5. Pola osilasi nilai keff hingga mencapai nilai konvergen

\section{Hasil Analisis Speedup}

Hubungan antara jumlah thread dan speedup yang didapatkan pada masing-masing komputer dapat dilihat di bawah ini.

Tabel 2. Perbandingan jumlah thread dengan speedup pada prosesor dual core

\begin{tabular}{|c|c|c|}
\hline No. & Jumlah thread yang digunakan & Speedup yang dihasilkan \\
\hline 1 & 1 & 0,99 \\
\hline 2 & 2 & 1,28 \\
\hline 3 & 3 & 1,11 \\
\hline 4 & 4 & 1,04 \\
\hline
\end{tabular}




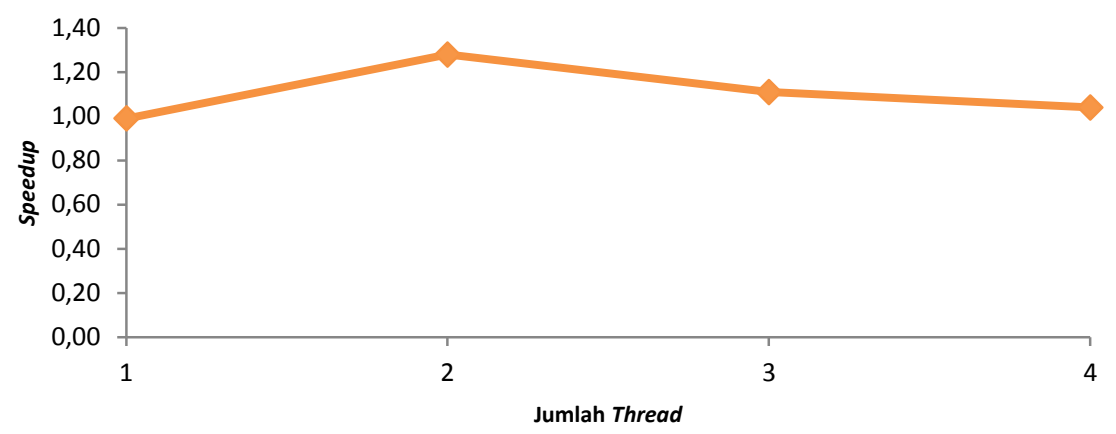

Gambar 6. Hubungan antara jumlah thread dengan speedup yang dihasilkan pada komputer dengan prosesor i3 $3120 \mathrm{M} 2,5 \mathrm{GHz}$ (2 core)

Tabel 3. Perbandingan jumlah thread dengan speedup pada prosesor quad core

\begin{tabular}{|c|c|c|}
\hline No. & Jumlah thread yang digunakan & Speedup yang dihasilkan \\
\hline 1 & 1 & 1,03 \\
\hline 2 & 2 & 1,31 \\
\hline 3 & 3 & 1,43 \\
\hline 4 & 4 & 1,53 \\
\hline 5 & 5 & 1,31 \\
\hline 6 & 6 & 0,94 \\
\hline 7 & 7 & 0,88 \\
\hline 8 & 8 & 0,73 \\
\hline
\end{tabular}

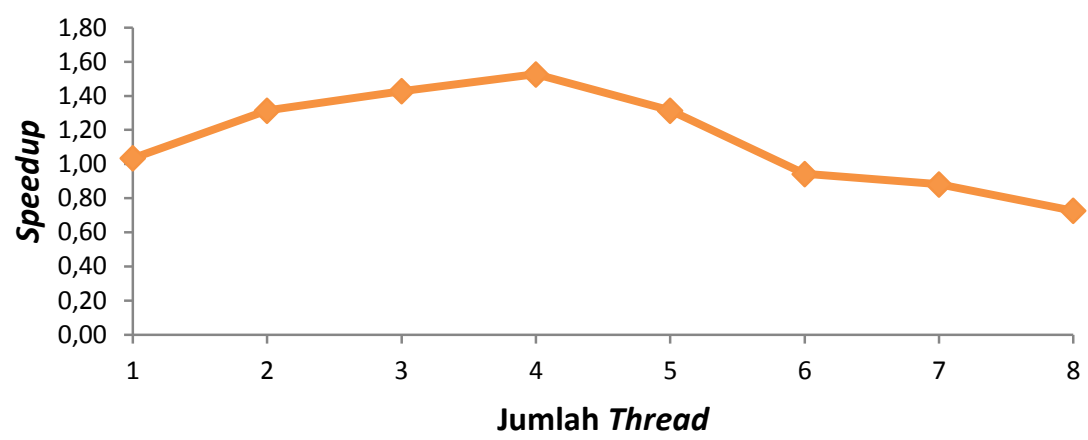

Gambar 7. Hubungan antara jumlah thread yang digunakan dan speedup yang dihasilkan pada komputer i7 3770 3,4 GHz (4 core)

Kedua komputer ini memiliki prosesor yang berkemampuan hyper-threading. Prosesor yang memiliki teknologi hyper-threading mampu menjalankan dua thread sekaligus dalam satu core. Sehingga misalnya untuk jenis prosesor dual core, prosesor tersebut mampu menjalankan 4 thread sekaligus. Itu alasan mengapa jumlah maksimal thread yang digunakan untuk masing-masing komputer ini adalah 4 dan 8 thread. Berdasarkan data di atas, untuk mendapatkan hasil speedup yang paling baik maka sebaiknya jumlah thread yang digunakan sama dengan jumlah prosesor yang dimiliki komputer tersebut.

Hubungan antara jumlah prosesor dengan speedup yang dihasilkan berdasarkan jumlah prosesor yang dimiliki sebuah komputer, dapat dilihat pada Gambar 8. 


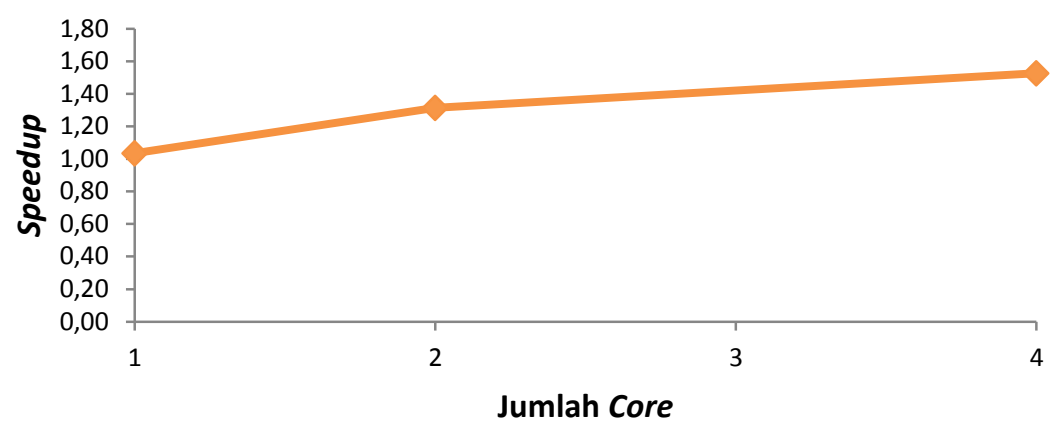

Gambar 8. Hubungan antara jumlah core dan speedup yang dihasilkan pada OpenMP

Tampak bahwa sifat skalabilitas dipenuhi, speedup meningkat dengan bertambahnya jumlah core. Dengan demikian diharapkan program ini dapat dijalankan dengan lebih cepat jika dipunyai prosesor atau PC dengan jumlah core yang lebih banyak. Saat ini telah dirilis produk prosesor dengan jumlah core 8 dan segera dirilis prosesor untuk server dengan jumlah core 16 yang mampu menjalankan 30 thread sekaligus .

\section{KESIMPULAN}

Kode program perhitungan persamaan difusi neutron telah berhasil disusun dalam bahasa $\mathrm{C}++$ dan OpenMP. Hasil benchmarking dengan program FI-ITBCHI menunjukkan bahwa kode yang ditulis menghasilkan keluaran fluks yang valid dengan tingkat kesamaan hingga 6 angka penting. Nilai speedup tertinggi dicapai dengan menggunakan jumlah thread yang sama dengan jumlah core pada prosesor. Speedup tertinggi untuk komputer yang menggunakan prosesor i3 $3120 \mathrm{M} 2,5 \mathrm{GHz}$ (2core) sebesar 1,28, sedangkan untuk komputer yang menggunakan prosesor i7 3770 3,4 GHz (4 core) sebesar 1,53.

\section{DAFTAR PUSTAKA}

1. Stacey, W. M., 2001, Nuclear Reactor Physics, Jhon Wiley \& Son Inc, Canada

2. Su'ud, Z., 2001, Komputasi Paralel dalam Analisa Reaktor Nuklir, Seminar Komputasi 2001, Bandung

3. Sastri, F., 2011, Komputasi Paralel Persamaan Difusi Neutron Pada Reaktor Cepat Menggunakan Iterasi Jacobi, Skripsi S1, Jurusan Fisika FMIPA UNAND, Padang

4. Taufiq, I., 2010, Komputasi Paralel Persamaan Burnup Pada Reaktor Cepat dengan Pendingin Pb-Bi Menggunakan Pemrograman Multicore, Disertasi S3, Jurusan Fisika FMIPA ITB, Bandung

5. Varga, R. S., 2009, Matrix Iterative Analysis, Springer Heidelberg Dordrecht London, New York 